\title{
Water quality of improved water sources and associated factors in Kibuku District, Eastern Uganda
}

\author{
Abel Wilson Walekhwa ${ }^{1}$ (1) $\cdot$ Moses Ntaro ${ }^{1} \cdot$ Peter Kawungezi $^{1} \cdot$ Evas Nimusiima $^{1}$. Chiara Achangwa ${ }^{3}$. \\ David Musoke $^{2} \cdot$ Edgar Mugema Mulogo $^{1}$
}

Received: 1 March 2021 / Accepted: 4 January 2022 / Published online: 22 February 2022

(c) The Author(s), under exclusive licence to Springer Nature Switzerland AG 2022

\begin{abstract}
Globally, billions of people still lack access to safe water, including basic drinking water services, particularly in subSaharan Africa. We analyzed water quality for improved water sources and associated factors in Kibuku district, Eastern Uganda. The mixed-methods study employed included; water quality analysis, a questionnaire survey, and key informant interviews conducted in the months of April-June 2020. A total of 249 improved water sources were sampled for analysis of bacteriological quality, $\mathrm{pH}$, and electrical conductivity. This was followed by a sanitary and people's attitudes survey at all the water sources visited. Among the water sources, $62.3 \%$ deep boreholes, $63.5 \%$ public tap stands, $14.3 \%$ rain-water harvesting tanks, and $28.6 \%$ protected springs had zero thermotolerant coliforms with $63.8 \%$ having acceptable $\mathrm{pH}$ levels (6.5-8.5) and 35.3\% having acidic levels (less than 6.4). Furthermore, 96.3\% deep boreholes, $99.1 \%$ public tap stands, all $(100 \%)$ rain-water harvesting tanks, and $50 \%$ protected springs had their turbidity levels in the acceptable range (less than 5NTUs). Additionally, only $22.1 \%$ of improved water sources had electrical conductivity in the acceptable range (less than 300 microSiemens). Among the 249 participants, majority (91.2\%) had low knowledge levels about various methods that can be used in improving the quality of water. Generally, water sources had poor quality of water which was attributed to agricultural activities, dirty water collection containers, and poor attitude to water chlorination. The Ministry of Health, Ministry of Water and Environment, and other agencies need to design sustainable and feasible models for water treatment for low resourced setting.
\end{abstract}

Keywords Water quality $\cdot$ Improved water sources $\cdot$ Uganda

\section{Abbreviations}

Pr Probability value

UNBS Uganda National Bureau of Standards

WHO World Health Organization

\section{Background}

Globally, 2.1 billion people lack access to safe water, and of those, 844 million people do not have basic drinking water services (Singh 2022). In sub-Saharan Africa, an estimate of 102 million people are still using unsafe surface water,

\section{Edgar Mugema Mulogo}

emulogo2000@gmail.com

Abel Wilson Walekhwa
wabelwilson@gmail.com
Moses Ntaro
ntaro2001@gmail.com
Peter Kawungezi
pkawungezi@must.ac.ug
Evas Nimusiima
enimusiimakm@gmail.com
Chiara Achangwa
ciaraacha@gmail.com
David Musoke
dmusoke@musph.ac.ug
1 Department of Community Health, Mbarara University of Science and Technology, P.O. BOX 1410, Mbarara, Uganda

2 Department of Disease Control and Environmental Heath, School of Public Health, College of Health Sciences, Makerere University, P.O. BOX 7072, Kampala, Uganda

3 Department of Public Health and Hygiene, University of Buea, P.O. BOX 63, Buea, Cameroon 
with an estimated 695 million people still using unimproved facilities (Baye 2021). Among these water sources, $41 \%$ are in rural areas and at least $53 \%$ are in Africa (Bain et al. 2014). Uganda, like many low-income countries, still lacks safe water, with recent report of contamination and mineral contents exceeding the normal levels (Lukubye and Andama 2017).

Uganda currently loses up to 389 billion shillings (\$177 million), which is equivalent to U\$5.5 per person per year or approximately $1.1 \%$ of national gross domestic product (GDP) annually due to poor water and sanitation (Water and Sanitation Program 2019). This burden is suffered as premature deaths of under-fives, loss of productivity among the sick populations, and out-of-pocket expenditure for health care services including treatment. The situation is worse in rural areas which are characterized by strong cultural beliefs and other sanitation-related practices that prevent people from treating drinking water and keeping water sources from contamination (Water and Sanitation Program 2019).

According to the Joint World Health Organization (WHO) and UNICEF Monitoring Programme, improved water sources refer to one that by the nature of its construction adequately protects the source from outside contamination, in particular with faecal matter and these include piped water connection into dwelling, yard or plot; public tap or standpipe; tube well or borehole; protected dug well; protected spring; rain-water collection (WHO 2021). Some of these water sources are not always safe, though they are hypothetically assumed the safest providers of water suitable for human consumption (Shaheed et al. 2014). Although a large population in Uganda has access to water, most of it is not safe. For example, in 2017, 60\% of improved water sources in Uganda's capital city, Kampala were contaminated (Murphy et al. 2017), which contributed to the deadly outbreak of typhoid fever that killed over 51 people (Kabwama et al. 2017). In addition, faecal contaminants were also detected in bottled water in Kampala, yet such water would be considered among the most safe improved water sources (Halage et al. 2015). This situation therefore calls for routine assessment of the quality of water from improved water sources across the country.

Some water treatment methods in Uganda and generally in Africa are not always effective in removing all contaminants. Indeed, water treated using modern methods such as stabilization pond systems and conventional treatment methods tend to leave contaminants like nitrates and sulphates which are known to have carcinogenic effects, yet such water is supplied to thousands of people in respective cities and municipalities (Wang et al. 2014). A pilot study done by Evidence Action in Kibuku district in 2015 as a baseline before an intervention of supply of chlorine dispensers for safe water showed that 213 improved water sources were contaminated by faecal matter and required improvement.
This informed interventions such as installation of chlorine dispensers across water sources which had been vandalised by the community claiming these dispensers have no value to them (KibukuDLG 2018). In this project, community leaders known as Village Health Teams (VHTs) were trained about this rationale of Chlorine in ensuring safety of water. These were then entrusted with Chlorine supplied by the implementing agency (Evidence Action Uganda) to be stored at their homes and would refill the dispensers in the water source at their catchment areas. These VHTs were part of the water user committee on such water sources and would sensitize the water users about the importance of chlorine to this water. This project was characterized by misuse of this chlorine by the VHTs for washing their clothes and sometimes selling off. Furthermore, these VHTs did not have adequate education to understand the behavioral dynamics of water users but also addressing the myths associated with chlorine in water (EvidenceAction 2017).

In addition, the quality of water from the improved water sources across the district needed to be known, because a number of residents continued to raise complaints about it. It was therefore necessary to conduct this study to assess the water quality of improved water sources and associated factors in Kibuku District, Eastern Uganda.

\section{Methods}

\section{Study design and setting}

An analytical mixed method cross-sectional study was conducted among 249 improved water sources in a rural-based district of Kibuku in Eastern Uganda, Africa. The study was conducted between April and June 2020. In addition to water quality analysis, a questionnaire survey and key informant interviews were also conducted. The water sources involved in the study included public tap stands, protected springs, rain-water harvesting tanks, and deep boreholes. These sources are categorized by WHO as improved water sources and perceived to be safer for human consumption in comparison with other sources. The water sources are located in rural areas in water user's land which is always donated to the government during the siting phase of a particular water source. Such water is surrounded by other socio-economic activities of the land donor. These activities could be farming/agriculture, animal grazing, mining, and others. The district is among those located in low land areas characterized with high water table, clay soils, and flooding when it rains. These water sources are always constructed using public resources through Ministry of Water and Environment (MoWE), district local governments, or development partners. 
Kibuku district is located in Eastern Uganda (Appendix Fig. 2) with a total population of 202,033, the majority of the population $(60.3 \%)$ being between the age of $0-17$ years, $51.8 \%$ being females, and with about $65.4 \%$ of the area being water logged (Nekaka et al. 2021). The district is bordered by Pallisa district in the North, Budaka district in the East, Butaleja district in the South, and Namutumba district in the West. Kibuku district has a total of 402 villages and 92 parishes and wards. Most of the residents in the district are peasants and the main economic activity in the area is agriculture. The district has 13 sub-counties and 5 town councils (TCs) (urban areas) of Kibuku, Bulangira, Tirinyi, Kasasira, and Kadama. Although the district is distributed by several improved water sources, public tap stands are mostly found in Kibuku, Kasasira, and Tirinyi TC. The other areas in the district use rain-water harvesting tanks and deep boreholes as their main sources of water.

Kibuku district has an average safe water access of $68 \%$ with rural areas having more access at $70 \%$ and urban access at $42 \%$. The district is largely served by deep boreholes (87\%) followed by shallow wells (7\%), protected springs (6\%), and public tap and rain-water harvest tanks at $1 \%$. The district has equally non-functional water sources and this is attributed to technical breakdown (50\%), poor water quality (25\%), and vandalism (25\%). These water sources are designed to have mostly communal management of operations ( $80 \%$ ) followed by institutional (8\%), private operators $(8 \%)$, and lastly individually managed (4\%). These different water sources are constructed using different sources of funding with central and local government as a main funder at $87 \%$ followed by non-government organizations like religious groups and other donors at $8 \%$ and lastly private funders at 5\% (ATLAS 2021).

Kibuku district was formerly under Pallisa district and its geological environment consists of a Gneissic Complex Formation or Gneiss and granitic formations of the Pre-Cambrian origins, and these form a principal source of ground water supplies (Nyende 2003). This study further showed that the area has three water-bearing zones (the upper, the middle, and the lower) and the metamorphic formations are widely weathered as you go deeper the earth, meaning that the lower zone of fresh geological granitic material are of a fractured bedrock. The hydrogeological investigation showed that groundwater in the study area lies below $30-70 \mathrm{~m}$ from the surface topography. The water table tends to lie at the base of the clay where fragments of the parent bedrock predominate the bedrock surface (Nyende 2007). This study area is occupied by rural populations who deeply on ground water sources as the main source of water including boreholes, wells, and springs. The public tap stands are recent innovations from National Water and sewerage corporation (NWSC) and her partners like Eastern water Umbrella which has promoted their installation and utilization in the peri-urban centers of our study area. Given their majority varsity, they contributed to more to our sample size. The public tap stands were installed for convenience and accessibility as they can be situated at people's homesteads but also stood minimal contamination from hydrological interactions.

The various improved water sources serve a total population ranging from 2 to 1000 depending on the type and availability of other existing water sources. The district had a total of 975 functional shallow and deep boreholes, 278 functional public tap stands, 48 functional rain-water harvesting tanks, and 87 protected springs (KibukuDLG 2018).

\section{Sample size and sampling}

The study was conducted among 249 improved water sources. The water sources included public tap stands, protected springs, rain-water harvesting tanks, and deep boreholes. This was computed using Kish-Leslie formula, 1965 with a single proportion of water quality estimated to be $25 \%$ following previous quarterly reports submitted to Atlas system at MoWE (KibukuDLG 2018). A 95\% confidence interval was considered. The improved water sources were randomly selected using stratified sampling (stratified by water source type) where each water source type contributed to the sample size proportionately based on the available quantity it had in the district.

A total of two samples were collected from each water source as selected samples were taken to different laboratories of regional water laboratory in Mbale district and Kibuku district for purposes of comparison as a form of quality assurance. Five key informants based at the Kibuku district headquarters who also doubled as members of the District Technical Planning Committee were purposively selected to participate in this study. The key informants were chosen given their role in making decisions and policies regarding water safety in the district as part of their mandate. These included the District Health Officer, District Water Officer, Assistant District Water officer in charge of sanitation, and Assistant District Water Officer in charge of mobilization and welfare and the secretary for works.

\section{Data collection and analysis}

To assess the quality of water from improved water sources, different parameters of water quality including physicochemical and bacteriological/microbiological analysis were examined. For physico-chemical parameters like water $\mathrm{pH}$, conductivity, and turbidity, these were measured onsite by observation using a pH meter, conductivity meter, and turbidity meter from Delaqua water kit, respectively. The measurements were done three times in a minute's interval and the average reading was recorded. During data collection, the study period was characterized by rainy season (average 
rainfall, high humidity and low temperatures). The Delaqua water testing kit was supplied from WagTech limited one of the leading suppliers of high standard water testing kits in the country (WAGTECH 2021).

For bacteriological quality, membrane filter technique was used. In this technique, a water sample of $100 \mathrm{ml}$ was incubated at $44^{\circ} \mathrm{C}$ for a period of $18 \mathrm{~h}$, and later, the number of coliform units counted using ${ }_{x}^{10}$ hand lens to show microbial growth. The numbers of these coliform forming units (CFUs) were recorded and tabulated in an Excel sheet and then later exported to STATA version 13 for both univariate bivariate analysis and multiple logistic regression. The results from these analyses were immediately recorded in the data collection forms and later entered into STATA version 13 for analysis. The results of the improved water sources were checked for conformity with WHO drinking water guidelines 2011 and Uganda National Bureau of Standards (UNBS) US EAS 12.

These standards were agreed and considered a threshold as follows: thermotolerant coliforms should be zero $(0 / 100 \mathrm{ml})$ : turbidity of drinking water/portable water should be less than 5 Nephelometric Turbidity Units (NTUs), electrical conductivity should be less than 300 micro siemens $/ 100 \mathrm{ml}$, and the $\mathrm{pH}$ of drinking water should be in the range of 6.5-8.5, with that less than 6.4 taken to be acidic and that beyond 8.5 taken to be alkaline. This study used these guidelines as a standard which determined the status of a particular type of water source.

To determine the factors and community practices influencing the quality of improved water sources, an observational electronic checklist/Sanitary Risk Score tool (Adopted from Risk of Contamination (ROC METHOD) WHO, 1997 was used. The tool had various parameters that are known to be risk factors for water contamination at various improved water sources such as location of pit latrine, availability of pit latrine within the 100 feet $(30 \mathrm{~m})$, radius of a water source, presence of refuse or solid waste management equipment within $10 \mathrm{~m}$ radius, protection of the water sources, accessibility of animals to the water source, existence of agricultural activities, and open defecation.

These factors were observed and noted, and later, categorization was made to show whether the water source had low risk, medium risk, or high risk. The risk scores of $0-30 \%$ were regarded as low, $39-50 \%=$ medium, $59-70 \%=$ high, and $79-100 \%$ very high risk (Mushi et al. 2012). During our study, a research assistant observed the conditions at the water source and scored accordingly. These results were tabulated and entered into STATA version 13 for analysis of association with results of water analysis of various parameters. Two-sided chi-square tests for association were computed to detect relationships between variables such as presence of thermo tolerant coliforms, high or low $\mathrm{pH}$, and high turbidity with the sanitary risk score from various improved water sources. Statistical significance was assessed at a p-value level of 0.05 .

The study also established the community knowledge, attitudes, and practices about water quality of improved water sources. A total of 249 participants aged 18 years and above found the respective improved water sources, were interviewed to assess their level of understanding of different water quality parameters, water treatment methods, and dangers of drinking water contaminated.

For qualitative data, a pretested key informant guide was used in data collection. The corresponding author made arrangements with these key informants for this interview. They dictated the time and location for the interview, since we did not want to interrupt usual work progress. They all consent by signing the consent forms before starting the interview, and then, permission was sought to record the sessions to enable further transcription. The audios were later transcribed verbatim by two research assistants. The corresponding author reviewed the transcripts by listening to the audio and tallying it with the transcripts. The transcripts were all exported to ATLAS.ti for deductive thematic analysis. The key themes that emerged informed the discussion section of this manuscript. The data collection tools were translated from English to the local language for use during data collection. The quantitative data were edited accordingly to assess correctness and later entered into the STATA version 13 for analysis.

\section{Results}

The study was conducted among 249 improved water sources in Kibuku district as follows: deep boreholes (44.0\%), public tap stands (47.6\%), protected springs (5.6\%), and rain-water harvesting tanks (2.8\%), Fig. 1.

\section{Bacteriological and physical quality of water}

Among the water sources, slightly above average (59.7\%) had no coliforms. However, $40.3 \%$ of the water sources had coliforms which were statistically significant $(P \leq 0.005)$ with the type of the water source and their risk categories $(P=0.002)$ at $95 \% \mathrm{CI}$ (Table 1$)$.

Regarding $\mathrm{pH}$, two-thirds of the water sources $(63.9 \%)$ had $\mathrm{pH}$ in the acceptable range according to WHO and UNBS (6.5-8.5). However, $35.3 \%$ of the water sources had acidic water ( $\mathrm{pH}$ less than 6.4), while very few had basic/alkaline range $(0.8 \%)(\mathrm{pH}$ greater than 8.5$)$. Concerning turbidity, the majority of the water sources (95.2\%) had a turbidity of less than 5 NTU which was within the WHO and UNBS recommended levels. For electrical conductivity, most of the water sources (77.9\%) 
Fig. 1 Different water source types

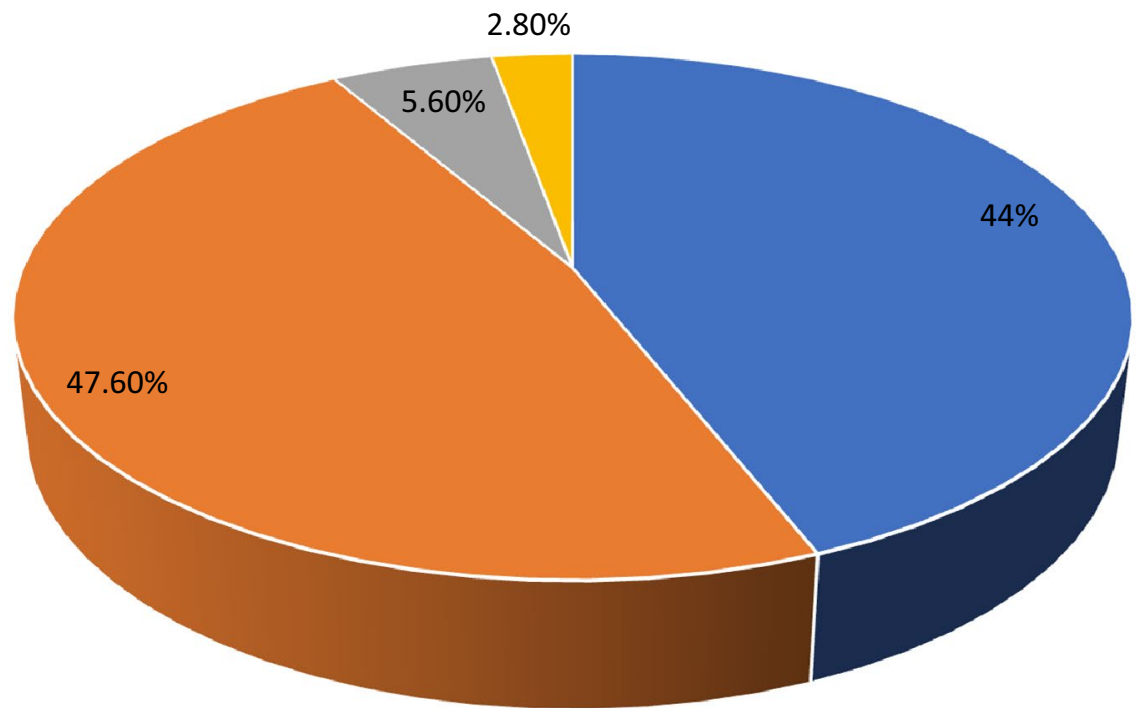

- Deep boreholes - Public tap stands " Protected springs " Rain Water harvest tanks
Table 1 Thermo-tolerant coliforms per improved water sources

\begin{tabular}{llll}
\hline Type of improved water sources & $\begin{array}{l}\text { Acceptable CFUs } \\
(0 / 100 \mathrm{ml})(\%)\end{array}$ & $\begin{array}{l}\text { Beyond acceptable CFUs } \\
(>0 / 100 \mathrm{ml})(\%)\end{array}$ & Total \\
\hline Deep boreholes & $68(62.4)$ & $41(37.6)$ & 109 \\
Public tap stands & $75(63.6)$ & $43(36.4)$ & 118 \\
Rain water harvest tank & $1(14.3)$ & $6(85.7)$ & 7 \\
Protected spring & $4(28.6)$ & $11(71.4)$ & 14 \\
Total & 148 & 101 & 249 \\
\hline
\end{tabular}

Pearson chi2(3) $=12.6941 \mathrm{Pr}=0.005$ had their electrical conductivity/dissolved salts of 22.9\%, which was beyond the WHO and UNBS recommended level.

\section{Factors affecting water quality}

Among the water sources, less than average (41.3\%) had at least one of the mostly observed risk factors of poor latrine situation, agricultural practices, poor waste management, or no fencing of water sources, followed by $29.3 \%$ that had all the four factors. In addition, $24.5 \%$ of the water sources had other risk factors such as use of dirty containers, clogged soak pits, access by animals, no functional water user committees at water points, and delayed cleaning of rain-water harvesting tanks, whereas $4.8 \%$ had no risk factors. The sanitary risk score results below were statistically significant $(P \leq 0.001)$ with the identified risk factors at various improved water sources (Table 2).

\section{Socio-economic data of participants}

Almost a third of the participants $(32.9 \%)$ were aged between 26 and 35 years, almost half $(40.2 \%)$ had attained at least primary level education, while slightly above third $39.0 \%$ had a monthly income of USD $1.3-8$ and majority were married $(79.5 \%)$ (Table 3$)$.

\section{Community knowledge and attitude on water quality}

Most of the participants only knew one type of water source, with wells and boreholes mostly reported (90.8\%), and $90.0 \%$ knew at least one type of improved water source (deep borehole). In addition, $85.1 \%$ of the participants knew at least one of the parameters (with color/turbidity and odor mostly reported parameters) used for assessing water quality, while $41.0 \%$ did not know any of the common factors that could affect the quality of improved water sources. Most of the 
Table 2 Risk factors affecting the quality of Improved water sources

\begin{tabular}{|c|c|c|c|c|c|}
\hline \multirow[t]{2}{*}{ Risk score } & \multicolumn{5}{|l|}{ Identified risks per improved water source } \\
\hline & $\begin{array}{l}\text { All four factors [poor latrine situation, agricultural practices, } \\
\text { poor waste management, no fencing of water sources }(\%) \text { ] }\end{array}$ & $\begin{array}{l}\text { At least one } \\
\text { factor }(\%)\end{array}$ & $\begin{array}{l}\text { Any other risk } \\
\text { factor }(\%)\end{array}$ & None $(\%)$ & Total $(\%)$ \\
\hline Low risk & $11(9.8)$ & $45(40.2)$ & 44 (39.3) & 12 (10.7) & 112 \\
\hline Medium risk & $48(44.4)$ & $43(40.0)$ & $17(15.7)$ & $0(0.0)$ & 108 \\
\hline High risk & $14(48.3)$ & $15(51.7)$ & $0(0.0)$ & $0(0.0)$ & 29 \\
\hline Total & 73 & 103 & 61 & 12 & 249 \\
\hline
\end{tabular}

Pearson chi2 $(6)=62.5201 \mathrm{Pr} \leq 0.001$

Table 3 Socio-economic data of the participants

\begin{tabular}{|c|c|c|}
\hline Parameter & $\begin{array}{l}\text { Frequency } \\
(n=249)\end{array}$ & Percentage $(\%)$ \\
\hline \multicolumn{3}{|l|}{ Age (years)/social } \\
\hline $18-25$ & 58 & 23.3 \\
\hline $26-35$ & 82 & 32.9 \\
\hline $36-50$ & 66 & 26.5 \\
\hline$>50$ & 43 & 17.3 \\
\hline \multicolumn{3}{|l|}{ Education level/social } \\
\hline None & 4 & 1.6 \\
\hline Primary & 100 & 40.2 \\
\hline Secondary & 98 & 39.4 \\
\hline Tertiary & 46 & 18.5 \\
\hline \multicolumn{3}{|c|}{ Average monthly income (USD)/economic } \\
\hline$<1.3$ & 30 & 12.1 \\
\hline $1.3-8$ & 97 & 40.0 \\
\hline $8.1-13.3$ & 40 & 16.1 \\
\hline$>13.3$ & 82 & 32.9 \\
\hline \multicolumn{3}{|l|}{ Marital status/social } \\
\hline Single & 43 & 17.3 \\
\hline Married & 198 & 79.5 \\
\hline Divorced & 1 & 0.4 \\
\hline Widowed & 6 & 2.4 \\
\hline \multicolumn{3}{|l|}{ Gender/social } \\
\hline Males & 127 & 51.0 \\
\hline Females & 122 & 49.0 \\
\hline \multicolumn{3}{|l|}{ Occupation/economic } \\
\hline Agriculture & 164 & 65.9 \\
\hline Others (business, students) & 85 & 34.1 \\
\hline
\end{tabular}

participants $(91.2 \%)$ knew at least one type of water treatment method (boiling was the most reported) with $90.5 \%$ of the participants knowing at least one of the dangers of drinking contaminated water (causing diseases was the most reported danger). Most of the participants believed that the quality of water from their water sources was always good (81.9\%), with only $8.8 \%$, believing that the quality of water was not good all the time. Less than half of the participants (41.2\%) believed that the mandate/role of ensuring safe water was with the owner of water sources, followed by $38.6 \%$ who believed it should be the role of water user committees, and $4.8 \%$ who believed it is the role of the government/district (Table 4).

For the qualitative results, all respondents were males with 04 employed as permanent civil servants in public service and 01 directly elected to the district council and later assigned temporarily as secretary for works for about 5 years. The respondents had more than 5 years of experience. 03 of the respondents had bachelor's degree, while two of them had diplomas. Many of the key informants believed that the quality of the water from their sources was good due to the many improved water sources available across the district, including those with existing chlorine dispensers. However, it emerged that some key informants believed some water sources such as protected springs were contaminated, as well as public tap stands due to leakages from pipes, with some of them reporting complaints from consumers of water doubting the quality of water.

"Well, the quality of improved water sources here in the district is okay because I can say we use improved technology. However, also remember that not all water can have the same quality like water from protected springs cannot be of the same quality like deep boreholes because protected springs derive their water from subsurface aquifers where as deep boreholes derive their water from lower aquifers." Member of the District Health Team.

"I am not sure about the quality of water in the district from those improved water sources because the previous water quality monitoring reports have shown that some of them are contaminated and actually this made us to compare the results from our water laboratory with that of ministry of water and environment in Mbale last year in September (2019), as we wanted to be sure." Member of the District Health Team.

\section{Discussion}

We interviewed people mostly aged $36-50$ years with majority having attained primary education. Majority of our respondents had an income range of USD 1.3-8 with many 
Table 4 Knowledge and attitude on water quality

Parameter (s)

Mention of common water sources (public tap stands, wells, deep boreholes, protected springs, rivers)

None of the above

At least three and above

4

Only one of the above

2

Not answered

None of these

All the four

At least one of the four

Not answered

Mention of parameters for assessing water quality (pH, turbidity, EC, E. coli, temperature, smell)

None of the above

$\begin{array}{lr}29 & 11.65 \\ 4 & 1.61 \\ 212 & 85.14 \\ 4 & 1.61\end{array}$

At least one parameter

Factors that affect quality of water (latrine situation, poor solid waste management, agricultural activities, no fencing)

Mention of all four factors

At least one of the factors

None of the above

Not answered

Methods for improving quality of water (boiling, chlorination, solar disinfection, sedimentation)

None of these

All these mentioned

At least one of these

Not answered

Dangers of drinking contaminated water (diseases, economic loss, loss of productive time, reputation loss due to outbreaks)

None of these

All these mentioned

At least one of these mentioned

Not answered

Belief on the quality of water

Always good
Changes during some seasons

Not good

None of above

Responsibility for improving water quality

Owners

$105 \quad 42.3$

Water user committee

$96 \quad 38.6$

Government/district

$12 \quad 4.8$

None of these

$26 \quad 10.4$

Not answered 3 of them married and practicing agriculture. Our findings, furthermore, showed that a good number of water sources in the district had risk factors that directly affect the quality of water which could lead to water-borne diseases such as cholera, typhoid, dysentery, and other diarrheal-related diseases. A high occurrence of water-borne diseases leads to loss of productive time spent in the health facilities as well as the economic loss from the costs incurred by people undergoing treatment. In addition, the findings show a number of risk factors that directly deteriorate the quality of water in the area such as poor waste management, open defecation practice, poor situation of latrines, and agricultural activities. 
We interviewed almost the same gender (males and females), aged 36-50 years with majority having attained primary education. Majority of our respondents had an income range of USD 1.3 -8 with many of them married and practicing agriculture. These findings could be attributed to the fact that this was a rural-based district in eastern Uganda where most of the people practice subsistence farming for a living and could explain why many respondents were farmers. The water users are both males and females in such places and this could explain almost a similar gender distribution among the people interviewed. This differs from previous scenarios where only females went to fetch water. Kibuku district is among the poorest districts in Uganda and this could explain why majority of our respondents had such an income. This was period was a school going time in the education calendar of Uganda and could explain why we had few respondents below 25 years of age and so we had more chances of meeting adults but also our selection criteria which prioritized those above 18 years of age. Our study does not agree that with a global study by Bouman et al. (2020) which showed that women were highly affected with issues of water and sanitation across the world. Furthermore, our study findings deviate from study conducted by Murtaza et al. (2020) in Pakistan which showed that children are always heavily affected with challenges of water quality. There is need to have age- and occupation-specific sensitizations in such rural districts as it will enhance learning.

Our study found a substantial number of improved water sources with bacteriological contamination. This contamination of water could be attributed to various risk factors that were identified in our study including poor situation of latrines where many were uphill and near water sources, poor solid waste management seen at various water sources, most of the water sources having children playing in the water, and the observed practice of open defecation greatly affect the bacteriological quality of water. The situation of water sources is contrary to the Public Health Act cap 281 specifications which recommends at least $100 \mathrm{ft}(30 \mathrm{~m})$ from any water sources to the pit latrine. These factors would lead to ground contamination of such water sources through ground water movement but also leaching of effluents from decomposing waste water in such locations. This contamination could also be explained by the hydrogeological nature of the area which has deep porous aquifer in some parts. The porousness could be arising from the continued weathering of the bed rock. Therefore, there could be chances of ground contamination. Open defecation could contribute to feacal matter which can find its way into open water sources like wells or unprotected springs more so during rainy seasons. Our study findings are in agreement with a study done in
Addis Ababa, Ethiopia which reported faecal/bacteriological contamination in various water sources including deep wells (Debela et al. 2018). Additionally, the public tap stands in our study also had microbial contamination which is similar to the findings to a study conducted in Ghana that showed that public infrastructure had faecal matter due to broken systems (Dongzagla et al. 2020; Prouty and Zhang 2016; Lagbas and Habito 2016). The public tap stands in this study area have their water tapped from a deep well located at the upper altitude at Tirinyi town council and pipes are used to transport this water to various areas. This deep well is treated and put in a reservoir tank located in the same location. The discovery of $E$. coli among public tap stands raises questions on the effectiveness of the treatment efforts at the main reservoir tank or the pipes that transport this water after treatment. Other possible risk factors such as leakages in pipes, corroded pipes, and irregular cleaning of storage tanks could explain this. This finding is the novelty of our study in this area, since no attention had been put on this reservoir tank. There is need to emphasize the addition of residual chlorine at the reservoir tank which would protect water on transit, such that any bacteriological contamination along the way can be treated. In addition, there is need for care during geological siting of new water sources but also regular geological monitoring of the existing water sources from time to time by the Ministry of Water and Environment.

Our findings on the physico-chemical parameters like $\mathrm{pH}$, conductivity, and turbidity were beyond the WHO drinking standards and this could be associated with the fact that the study was conducted during rainy season in this study area (April-June 2020) which could have affected the turbidity of the water. This would be possible, since some water sources were not protected and, therefore, turbid surface run off would compromise the quality of such water sources. Our sanitary inspection also showed that agricultural activities specifically rice growing were conducted in the vicinity of the water sources and this would compromise the turbidity of the water. Furthermore, the hydrogeological nature of the area could predispose such water sources to contamination as the water goes through the clay layer located under the bedrock and this could affect its turbidity. In addition, it should be noted that the water from this had high conductivity an indication of more ions in the area which could contribute to the acidic nature for many water sources. This high salt (ions) content in such water hinders the uptake of such water, since it increases the hardness of water and some people do not like salty water. Our study findings are in agreement with a study conducted by Bwire et al. (2020) which was conducted in communities similar to our study area but also found turbidity, $\mathrm{pH}$, and conductivity levels 
above the WHO recommended levels. These results do not agree with a study conducted by Saturday et al. (2021) in western Uganda around Lake Bunyonyi which showed that the physico-chemical parameters of lake water were within the WHO drinking standards. There is need to improve the quarterly water quality monitoring conducted by the district water department to focus on what ions exist in the study area. Furthermore, there is need for deliberate efforts in addressing the sanitary risks at various water sources coupled with protection of water sources.

The sanitary risk factors established in our study such as poor waste management, agricultural activities at the vicinity of the water sources, dirty jerricans used, and no fencing of water sources to affect the quality of water from improved water sources have been found in other studies conducted in sub-Saharan Africa including proximity of septic tanks (Arwenyo et al. 2017; Adams et al. 2016). These septic tanks, if not well constructed and maintained, can lead to contamination of ground water hence are of public health concern.

The risk factors found in Kibuku district are partly due to the fact that most of these improved water sources had no functional water user committees to support their operation and maintenance. This could also explain the challenges faced by the Evidence Action Project Uganda in the district where a number of water sources had inactive water user committee members hence leaving few VHTs to supply and store chlorine to more than one water source. There is need to conduct refresher training for water user committee members so that they can appreciate their roles in ensuring protection of water sources from any form of contamination. Furthermore, the continued deterioration of water quality in the district could be attributed to the fact that water quality is not a key indicator reported by either the health department or water department of the lower local government authorities, thus less prioritized by the stakeholders. These identified sanitary risk factors that lead to contamination of water sources need to be brought to the attention of the district health office and line ministries for attention through synchronized reporting system from water sources through VHTs or any water user committee to the national level. This will trigger action but also highlight for the future partners the gaps that need attention.

Ideally, people in communities who have sufficient knowledge on various water sources, improved water sources, dangers of consuming contaminated water, and parameters of water quality. This is very important in deciding the which water source to get water from but also appreciate the need to treat or store water safely in bid to maintain good health. The health belief model (HBM) concept of perceived susceptibility would be appreciated if the community members knew the risks they are exposed to. Our study established that community knowledge on some key water quality issues such as improved water sources, parameters for water quality, and water treatment methods need to improve, since many people knew little about pertinent parameters. These low levels on all water parameters which would be critical decision-making could be attributed to low sensitization done by the water user committees or VHTs and technical staff like the Assistant/Environmental Health officers or community development officers. It was evident that some water user committees (WUC) were non functionable but even those with WUC few did not have record of sensitization sessions for each water source. A number of administrative areas commonly known as sub-counties or town councils (Nandere, Kakutu, Kenkebu, Kadama Sub County, Bulangira subcounty, Goligoli, Nankodo) did not have technical staff who could champion these initiatives in such areas of jurisdiction.

Most of the participants only knew one type of water treatment method (boiling), which still shows the urgent need to have more sensitization, such that they can appreciate other treatment methods like use of chlorine disinfection. This method has been promoted by Evidence Action Uganda through installation of chlorine dispensers, and it has been established in studies conducted in Kenya, Uganda, and Malawi that people who had knowledge about chlorine were 3.2 times more likely to use them (Kahuho et al. 2019). Most of the participants only knew leading to diarrheal diseases as the danger of drinking contaminated water, while still a section of participants knew none. This finding is related to other studies conducted in Nigeria (Okoh et al. 2020), Kenya, Uganda, and Malawi that showed that community empowerment through sensitization in a bid to increase their knowledge levels would greatly influence the uptake of safe water from various water sources (Kahuho et al. 2019).

These findings on community knowledge on water quality are in line with the other studies conducted in Uganda where community's knowledge and practices about the safe water chain were low (Ssemugabo et al. 2019; Musoke et al. 2018). These studies were done in slum areas of Kampala among people of low economic class which has relatively similar socio-demographics of our study area. Our study findings are in agreements conducted in Australia as reported by Russell et al. (2020) who reported that most people make decisions on either to consume water basing on the physical appearance of water but also considered boiling as the most appropriate water treatment method. Similar results were also reported in Indonesia where it was clear that community behavioral models are critical in ensuring water quality maintenance (Syafri et al. 2020). 
There is need to conduct routine community sensitization on all key parameters of water quality; also, refresher trainings for the WUC would build a sustainable workforce. This would also contribute to better understanding of water quality, hence improving their practices regarding operation and maintenance of water sources. Furthermore, there is also need to recruit technical staff and facilitate their field activities to ensure execution of water safety tasks and agenda. This would contribute to the country's realization of sustainable development goal \#6.

In addition, the absence of/inactive physical planning committees in most of the district lower local governments (sub-counties and town councils) as established in our study is similar to other studies conducted across Africa inactive or nonexistent planning committees can be attributed to the earlier centralized recruitment process by most African countries, which limits the enforcement of policies and bylaws for the safety of such rural water supplies. This limitation leaves communities with compromised physical developments that greatly affect the geological and soil composition, hence influencing the quality of water (Whaley et al. 2019; Godfrey et al. 2018).

The poor attitude of community members about water quality as established in our study is in agreement with another study conducted in Rakai district, Uganda, where poor attitudes toward operation and maintenance of water sources were due to low sensitization for their low knowledge levels, as well as their low levels of education (Murduca 2018). In our study, a good proportion of the participants believed that it was the government or district leadership or water user committee role to ensure the safety of the water. This could be an issue of less information on the burden of water quality to household income or productive time. There is a need to change this poor mindset among community members if improvement in water quality is to be achieved. Indeed, with improved attitudes of the community, they are likely to see themselves as being responsible for ensuring the safety of the water they use hence put in place appropriate measures that will ultimately contribute to the realization of the sustainable development goal 2030 (6.2) that is by

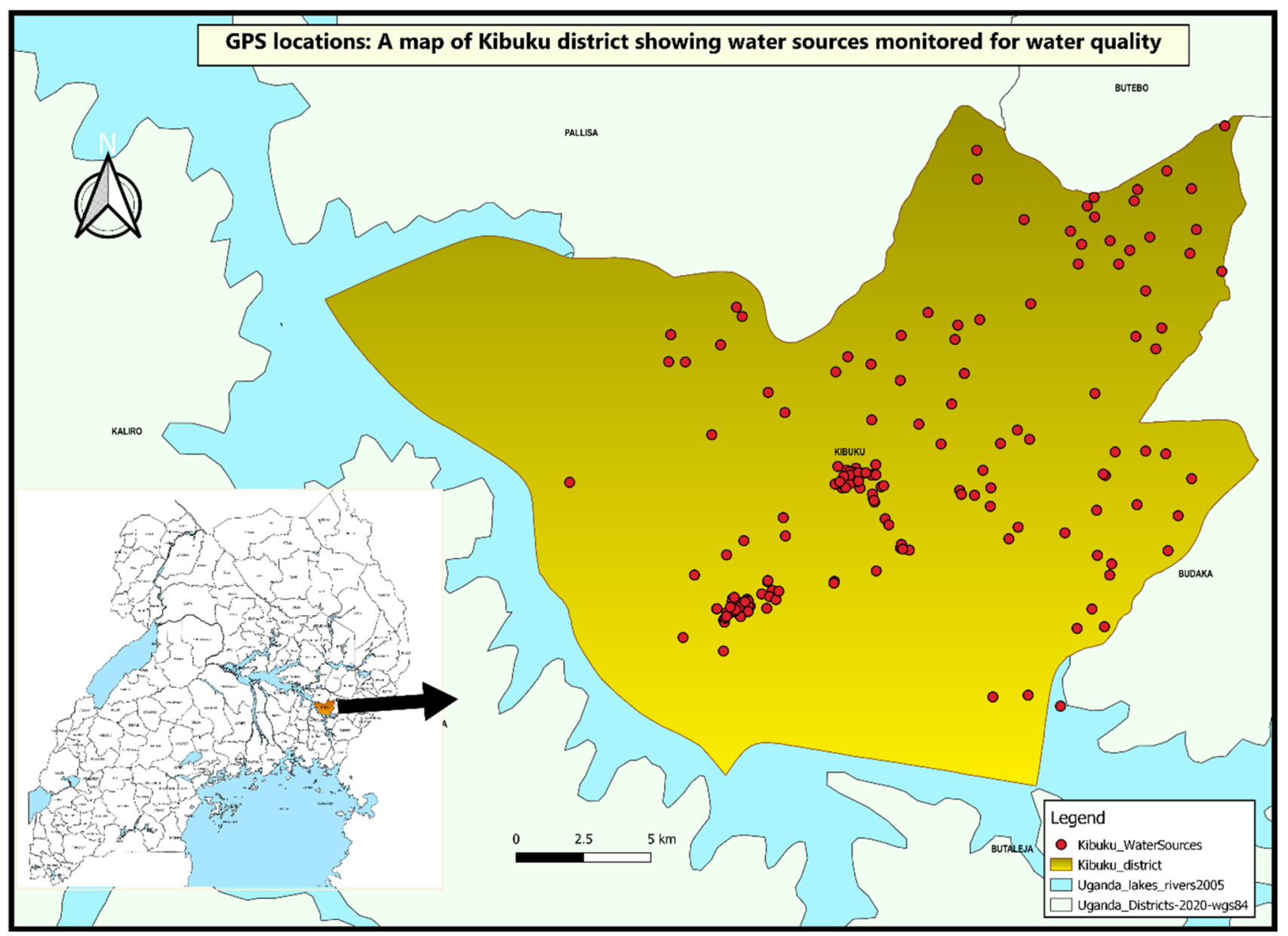

Fig. 2 Map of Uganda showing Kibuku district and location of water sources studied 
2030, achieve access to adequate and equitable sanitation and hygiene for all and end open defecation, paying special attention to the needs of women and girls and those in vulnerable situations. This finding community attitude is in agreement with a study conducted in Zimbabwe that showed that water user committees play a significant role in sustaining the functionality of water sources in rural areas (Kativhu et al. 2022). Further studies conducted in Malaysia were in agreement with our findings and reported the need to improve community participation in water management as a sustainable model for water quality (Ahmed et al. 2020).

Our study had a number of strengths including: data were collected from various sources including boreholes, wells, springs, and rain-water harvest tanks. Also, variety of investigations were conducted including water quality analysis, sanitary inspection of water sources, questionnaire survey among community members, and key informant interviews, which enabled triangulation of findings, and our study is the first of its kind in this study area exploring diversity of water sources in this study area. We provide information on possibility of contamination of public tap stands arising from main reservoir tanks which previously had been assumed to be well maintained and protected from any form of contamination. This study could potentially inform some actions from policy makers and safe water advocates across the world about likely sanitary risks to water quality in such limited resourced countries. However, this study also had limitations. For examples this study was conducted during lockdown in Uganda when schools and other institutions were closed due to the COVID-19 pandemic, and water points near or in school compounds were not functional; hence, the earlier intended sample size of 289 could not be achieved. In addition, another limitation of our study is that it did not conduct geological quality assessments but also specific tests on the type of ions that could be contributing to the high turbidity of water in the area, hence the inability to attribute these high turbidity levels /dissolved salts to a particular one for future directed intervention. Finally, the study was conducted during a rainy season (April, May, and June 2020); hence, the results may not be consistent with other seasons of the year.

\section{Conclusions}

Some water sources in Kibuku district had physico-chemical and bacteriological contamination beyond the WHO recommended levels, and this calls for feasible and sustainable water treatment methods for a rural-based and low-income earner. Majority of the water sources had sanitary risks which exposes the water to contamination; there is need for empowerment of water source management committees for better operation and maintenance of these improved water sources. We recommend more studies on identification of ions contributing to high conductivity of water in such water sources and cost-benefit analysis of efforts of chlorination project that has been in the study area for the 8 years (Fig. 2).

\section{Appendix: Supplementary materials}

The team has also attached some supplementary materials to aid the review process like the Approval letter from Mbarara University of Science and Technology Research Ethics Committee ( labelled as Approval letter), Approval letter from Uganda National Council of Science and Technology (UNCST), Also responses from the key informants that were interviewed labelled as KI responses, Also the quantitative data collected about the water sources (labelled as Last water) and lastly the sampling frame that was generated from the 947 water sources in Kibuku district (labelled as Kibuku sources).

Acknowledgements The study team acknowledges the support from Mr. Opio Derrick Chris (supported data cleaning), Isabella Atuganyire Walekhwa (supported in data collection), Martha Dorcus Nalweyiso (Supported in GPS data cleaning and ploting of GPS Map), and Staff of Kibuku District Local Government for according us audience. Special gratitude goes to the Mr. Julius Nkabi (District Water Officer), Mr. Denis Mwesige (Assistant District Water Officer-Sanitation), Moses Mwiraguzu (Assistant Water Officer-Mobilization), and Dr. Buyinza Godfrey Kagawa (District Health Officer).

Authors' contributions AWW: protocol design, processing of ethical approvals, data collection, grants application, accountability of funds, data analysis, manuscript writing for publication, and responding to comments from the journal. EMM and DM: technical mentorship, protocol design, data analysis, manuscript writing, and editions. MN, EN, CA, and PCK: protocol designs, data collection, data analysis, and manuscript editions.

Funding The research was both financially and technically supported by a grant from Massecutes General Hospital through the Global health Collaborative and First mile Programme at the Faculty of Medicine, Mbarara University of Science and Technology (http://ghcuganda.org/ about-us/). The Global Health collaborative staff did not participate in the design of the study, data collection, analysis, and interpretation of the data or the writing of the paper.

Availability of data and materials All data supporting our findings are contained in the paper. There are no restrictions to data sources; however, details of the full data may be accessed through Mr. Abel Wilson Walekhwa (corresponding author), Department of Community Health, Mbarara University of Science and Technology, PO Box 1410, Mbarara, Uganda, e-mail:wabelwilson@gmail.com.

\section{Declarations}

Conflict of interest All authors declare no competing interests.

Ethical approval Ethical approval for this study was obtained from the Research Ethics Committee at Mbarara University of Science and 
Technology (reference number MUREC 1/7) and Uganda National Council of Science and Technology (HS641ES). Permission to conduct this study was also granted by the office of the Chief Administrative Officer of Kibuku district local government.

Informed consent Informed consent was obtained from all study participants. Written informed consent was obtained from the individual participants before their participation in the study.

Consent for publication Not applicable.

\section{References}

Adams EA, Boateng GO, Amoyaw JA (2016) Socioeconomic and demographic predictors of potable water and sanitation access in Ghana. Soc Indic Res 126:673-687

Ahmed MF, Mokhtar MB, Alam L (2020) Factors influencing people's willingness to participate in sustainable water resources management in Malaysia. J Hydrol Reg Stud 31:100737

Arwenyo B, Wasswa J, Nyeko M, Kasozi G (2017) The impact of septic systems density and nearness to spring water points, on water quality. Afr J Environ Sci Technol 11:11-18

Atlas (2021) Water supply atlas, Kibuku District [Online]. Water ATLAS, Ministry of Water and Environment. http://wsdb.mwe. go.ug/index.php/reports/district/101. Accessed 2 Oct 2021

Bain R, Cronk R, Hossain R, Bonjour S, Onda K, Wright J, Yang H, Slaymaker T, Hunter P, Prüss-Ustün A (2014) Global assessment of exposure to faecal contamination through drinking water based on a systematic review. Trop Med Int Health 19:917-927

Baye D (2021) Sustainable development goals (SDG) target 6.2 in Ethiopia: challenges and opportunities. Open Access Libr J 8:1-28

Bouman-Dentener AM (2020) Women, Health and Water Governance. The goal of the proceedings is to attend a broad audience to the improvement of regional communities through extension of women's role in water sector management. The articles in the proceedings are grouped into three main blocks:"Women and water education", "Women and access to water" and "Women in water resource management". The articles describe examples from Central Asia and some other countries, p 39

Bwire G, Sack DA, Kagirita A, Obala T, Debes AK, Ram M, Komakech H, George CM, Orach CG (2020) The quality of drinking and domestic water from the surface water sources (lakes, rivers, irrigation canals and ponds) and springs in cholera prone communities of Uganda: an analysis of vital physicochemical parameters. BMC Public Health 20:1-18

Debela TH, Beyene A, Tesfahun E, Getaneh A, Gize A, Mekonnen Z (2018) Fecal contamination of soil and water in sub-Saharan Africa cities: the case of Addis Ababa, Ethiopia. Ecohydrol Hydrobiol 18:225-230

Dongzagla A, Jewitt S, O'hara S (2020) Seasonality in faecal contamination of drinking water sources in the Jirapa and Kassena-Nankana Municipalities of Ghana. Sci Total Environ $752: 141846$

Evidence Action (2017) Dispensers for safe water: an updated review of the evidence [Online]. https://www.evidenceaction. org/dispensers-for-safe-water-an-updated-review-of-the-evide nce/. Accessed 01 Aug 2021

Godfrey O, Denis S, Okidi LP (2018) Factors affecting communication and information sharing for water resource management in Lake Victoria. In: Handbook of climate change and biodiversity. Springer
Halage AA, Ssemugabo C, Ssemwanga DK, Musoke D, Mugambe RK, Guwatudde D, Ssempebwa JC (2015) Bacteriological and physical quality of locally packaged drinking water in Kampala, Uganda. J Environ Public Health 2015:942928

Kabwama SN, Bulage L, Nsubuga F, Pande G, Oguttu DW, Mafigiri R, Kihembo C, Kwesiga B, Masiira B, Okullo AE (2017) A large and persistent outbreak of typhoid fever caused by consuming contaminated water and street-vended beverages: Kampala, Uganda, January-June 2015. BMC Public Health 17:23

Kahuho PK, Nassali PN, Maina J, Byatta P (2019) Optimizing access to safe water through chlorinated dispensers in Rural Kenya, Uganda and Malawi

Kativhu T, Madzivanyika TT, Nunu WN, Macherera M, Chinyama A (2022) Sustainability of water facilities under community based management in Zimbabwe. J Water Supply Res Technol-Aqua 71:19-30

Kibukudlg (2018) Annual sector report. Water Atlas: Ministry of Water and Environment

Lagbas AJ, Habito CD (2016) Water quality of traditional communal drinking wells: the case of a fishing community in Panukulan, Polillo Island, Quezon, Philippines. J Nat Stud 15:41-57

Lukubye B, Andama M (2017) Physico-chemical quality of selected drinking water sources in Mbarara Municipality, Uganda. J Water Resour Prot 9:707-722

Murduca JV (2018) Assessment of drinking water quality management and a treatment feasibility study for brick by brick water storage tanks in Rakai Uganda

Murphy J, Kahler A, Nansubuga I, Nanyunja E, Kaplan B, Jothikumar N, Routh J, Gómez G, Mintz E, Hill V (2017) Environmental survey of drinking water sources in Kampala, Uganda, during a typhoid fever outbreak. Appl Environ Microbiol 83:e01706-e 1717

Murtaza B, Nazeer H, Amjad M, Imran M, Shahid M, Shah NS, Farooq ABU, Amjad M, Murtaza G (2020) Hydrogeochemical investigation of arsenic in drinking water of schools and age dependent risk assessment in Vehari District, Punjab Pakistan: a multivariate analysis. Environ Sci Pollut Res 27:30530-30541

Mushi D, Byamukama D, Kirschner AK, Mach RL, Brunner K, Farnleitner AH (2012) Sanitary inspection of wells using riskof-contamination scoring indicates a high predictive ability for bacterial faecal pollution in the peri-urban tropical lowlands of Dar es Salaam, Tanzania. J Water Health 10:236-243

Musoke D, Ndejjo R, Halage AA, Kasasa S, Ssempebwa JC, Carpenter DO (2018) Drinking water supply, sanitation, and Hygiene promotion interventions in two slum communities in Central Uganda. J Environ Public Health

Nekaka R, Oboth P, Nteziyaremye J, Gavamukulya Y, Ssenyonga LV, Iramiot JS (2021) Sero prevalence and factors associated with Helicobacter pylori infection in a rural population in Eastern Uganda a community cross sectional study. Prim Health Care Open Access 11:1-9

Nyende J (2003) Evaluation of groundwater resource potential of Pallisa district in Eastern Uganda. University of the Free State

Nyende J (2007) Groundwater quality and sustainability in granitised-fractured aquifers, Pallisa district, eastern Uganda. WIT Trans Ecol Environ 103:263-272

Okoh EO, Miner CA, Envuladu EA, Mohammed A, Ugochi J (2020) Effect of household water treatment on microbiological quality of drinking water in rural communities of Plateau State, Nigeria: a comparative study of two treatment modalities

Prouty C, Zhang Q (2016) How do people's perceptions of water quality influence the life cycle environmental impacts of drinking water in Uganda? Resour Conserv Recycl 109:24-33

Russell S, Ens E (2020) 'We don't want to drink that water': crosscultural indicators of billabong water quality in remote Indigenous Australia. Mar Freshw Res 71:1221-1233 
Saturday A, Lyimo TJ, Machiwa J, Pamba S (2021) Spatio-temporal variations in physicochemical water quality parameters of Lake Bunyonyi, Southwestern Uganda. SN Appl Sci 3:1-14

Shaheed A, Orgill J, Montgomery MA, Jeuland MA, Brown J (2014) Why? improved? Water sources are not always safe. Bull World Health Organ 92:283-289

Singh V (2022) Sustainable development and climate change. Research anthology on measuring and achieving sustainable development goals. IGI Global

Ssemugabo C, Wafula ST, Ndejjo R, Oporia F, Osuret J, Musoke D, Halage AA (2019) Knowledge and practices of households on safe water chain maintenance in a slum community in Kampala City, Uganda. Environ Health Prev Med 24:45

Syafri S, Surya B, Ridwan R, Bahri S, Rasyidi ES, Sudarman S (2020) Water quality pollution control and watershed management based on community participation in Maros City, South Sulawesi, Indonesia. Sustainability 12:10260

WAGTECH (2021) Water Analysis Technologies [Online]. WagTech website: Wagtech. https://www.palintest.com/product-categ ories/wagtech/. Accessed 7 July 2021
Wang H, Wang T, Zhang B, Li F, Toure B, Omosa IB, Chiramba T, Abdel-Monem M, Pradhan M (2014) Water and wastewater treatment in Africa-current practices and challenges. Clean: Soil, Air, Water 42:1029-1035

Whaley L, Macallister DJ, Bonsor H, Mwathunga E, Banda S, Katusiime F, Tadesse Y, Cleaver F, Macdonald A (2019) Evidence, ideology, and the policy of community management in Africa. Environ Res Lett 14:085013

WHO (2021) Improved Drinking Water Sources [Online]. WHO. https://sswm.info/content/improved-drinking-water-sources. Accessed 1 Aug 2021

Publisher's Note Springer Nature remains neutral with regard to jurisdictional claims in published maps and institutional affiliations. 